\title{
- OCZEKIWANIA PACJENTÓW Z TERENU WSCHODNIEJ POLSKI WOBEC LEKARZA PODSTAWOWEJ OPIEKI ZDROWOTNEJ
}

\section{EXPECTATIONS OF PATIENTS FROM EASTERN POLAND RELATIVE TO THE PRIMARY HEALTH CARE DOCTORS}

\author{
Ewa Humeniuk ${ }^{1}$, Katarzyna Pawlikowska-Łagód², Olga Dąbska ${ }^{1}$, Paulina Mazurek ${ }^{1}$ \\ ${ }^{1}$ Zakład Patologii i Rehabilitacji Mowy, Uniwersytet Medyczny w Lublinie \\ ${ }^{2}$ Zakład Etyki i Filozofii Człowieka, Uniwersytet Medyczny w Lublinie
}

DOI: https://doi.org/10.20883/pielpol.2018.19

\begin{abstract}
STRESZCZENIE
Wstęp. Oczekiwania wobec świadczeniodawców usług medycznych na przestrzeni lat znacząco się zmieniły. Wraz z większą dostępnością świadczeń opieki zdrowotnej pacjenci stali się bardziej roszczeniowi i częściej zwracają uwagę na jakość udzielanych porad. Rosnące oczekiwania pacjentów zauważyć można zwłaszcza względem realizatorów podstawowej opieki zdrowotnej.

Cel. Celem niniejszej pracy było poznanie oczekiwań pacjentów makroregionu lubelskiego wobec lekarza podstawowej opieki zdrowotnej.

Materiał i metody. Badanie przeprowadzono na grupie 100 pacjentów podstawowej opieki zdrowotnej. Narzędzie badawcze stanowił standaryzowany kwestionariusz: Lista Oczekiwań Pacjenta (PRF). Analizy materiału badawczego dokonano przy użyciu programu IBM SPSS Statistics.

Wyniki. Uzyskano istotną statystycznie zależność między zmiennymi socjodemograficznymi a chęcią otrzymania otuchy w trudnej chwili. Niezależnie od zmiennych socjodemograficznych badani wykazywali znaczącą potrzebę otrzymania od lekarza POZ porad na temat działań, które w pozytywny sposób wpłynęłyby na stan ich zdrowia i wykazywali średni stopień zaciekawienia prawdopodobnymi problemami zdrowotnymi, z jakimi, być może, będą się zmagać w przyszłości.

Wnioski. Poziom satysfakcji i spełnienia oczekiwań pacjentów rozpatrywany jest jako najlepsze źródło informacji o jakości usług medycznych. W znaczącej większości respondenci domagają się od lekarza POZ omówienia wyników badań, uzyskania informacji o prawdopodobnym przebiegu choroby, jej objawach i skutkach ubocznych, sposobie przyjmowania lekarstw, podejmowanym leczeniu czy wypisania skierowania do lekarza specjalisty.
\end{abstract}

SŁOWA KLUCZOWE: pacjent, lekarz POZ, oczekiwania.

\section{Wprowadzenie}

Od dłuższego czasu w Polsce trwa publiczna debata dotycząca jakości funkcjonującego systemu opieki zdrowotnej. Za główne wyzwanie stojące przed systemem ochrony zdrowia uważa się kształtowanie na

\begin{abstract}
Introduction. Expectations relative to providers of medical services over the years have changed significantly. Along with the greater availability of health care services, patients have become more demanding and pay attention to the quality of the advice provided. The increasing expectations of patients can be observed especially relative to the implementers of primary health care.

Aim. The aim of the research was to assess the expectations of patients from Eastern Poland relative to the primary health care doctors.

Material and methods. The surveyed group consisted of 100 patients from facilities providing primary health care services. The research tool was a standardized questionnaire Patient Request Form (PRF). Analysis of the gathered data was done using IBM SPSS Statistics software.

Results. A statistically significant relationship between sociodemographic variables and the willing to receive support in difficult moments. Regardless of the socio-demographic variables, respondents demonstrated a significant need to obtain advice about the activities that had a positive effect on their health from the primary health care doctors, and demonstrated the average degree of curiosity in probable health problems which they are likely to face in the future.

Conclusions. The level of satisfaction and fulfillment of patient expectations are considered the best source of information about the quality of medical services. Most respondents demand from primary health care doctors to discuss the results of research, obtain information about the probable course of the illness, symptoms and side effects of the disease, pharmacotherapy, undertaken treatment or referrals to specialists.
\end{abstract}

KEYWORDS: patient, primary health care doctor, expectations.

odpowiednio wysokim poziomie relacji lekarz - pacjent tak, aby opierały się one na równoważności i poszanowaniu potrzeb obu stron [1]. Zdaniem Małeckiej i Marcinkowskiego to „(...) świadczeniobiorca usług medycznych kształtuje współczesny rynek tych usług na 
płaszczyźnie subiektywnej poprzez wyrażanie swoich opinii i oczekiwań” [2]. Stopień spełnienia oczekiwań pacjentów rozpatrywany jest jako najlepsze źródło informacji o jakości usług medycznych z perspektywy pacjenta. Palczewska donosi, iż pacjenci oczekują przede wszystkim od przedstawicieli służby zdrowia ciągłości procesu terapeutycznego, komfortu psychicznego, dobrej relacji z personelem [3].

Rosnące oczekiwania pacjentów zauważyć można zwłaszcza względem realizatorów podstawowej opieki zdrowotnej. Na lekarzu rodzinnym ciąży nie tylko obowiązek diagnozowania i leczenia, ale i pełnienia funkcji opiekuna rodziny [4]. Lekarz POZ uważany jest za „(...) kluczowy element systemu opieki zdrowotnej. Jest nie tylko podstawowym źródłem kontaktu między pacjentem a lekarzem, ale również w wielu przypadkach inicjuje indywidualne środki zapobiegawcze i lecznicze” [5]. Sprawowana przez niego opieka „(...) powinna być opieką wszechstronną, zintegrowaną i ciągłą, a jej zakres powinien być na tyle szeroki, by odpowiadała ona na większość problemów zdrowotnych, a przede wszystkim gwarantowała takie usługi, jak: promocja zdrowia, profilaktyka, wczesna diagnostyka, leczenie, rehabilitacja, opieka paliatywna oraz wsparcie w zarządzaniu samą opieką" [6]. Dlatego też spełnianie oczekiwań pacjentów odnośnie świadczeń lekarza POZ jest niezwykle istotne.

\section{Cel pracy}

Celem niniejszej pracy było poznanie oczekiwań pacjentów makroregionu lubelskiego wobec lekarzy podstawowej opieki zdrowotnej.

\section{Materiał i metody}

Grupę badaną stanowiło 100 pacjentów placówek udzielających świadczeń o charakterze podstawowej opieki zdrowotnej: NZOZ Ośrodek Zdrowia w Czemiernikach $(n=50)$ i Przychodnia 1 Wojskowego Szpitala Klinicznego z Polikliniką SPZOZ w Lublinie ( $n=50)$. Ponad połowę (54\%) ankietowanych stanowiły kobiety. Najmłodszy respondent miał 19, a najstarszy - 76 lat, przy czym średnia wieku ankietowanych wyniosła 58 lat. Wśród ankietowanych dominowały osoby z wykształceniem średnim (36\%) i wyższym (35\%). Mieszkańców wsi i miasta było po 50\%.

Przeprowadzając badania, posłużono się metodą sondażu diagnostycznego, techniką ankietową. Narzędziem badawczym był standaryzowany kwestionariusz: Lista Oczekiwań Pacjenta (PRF) autorstwa Petera Salmona i Johna Quine'a w polskiej adaptacji Zygfryda Juczyńskiego. Jest to narzędzie samoopisu, składające się z 18 stwierdzeń dotyczących odczuć pacjenta po konkretnej wizycie lekarskiej, związanych m.in. z zaangażowaniem lekarza w wyjaśnienie choroby, uzyskaniem wsparcia czy informacji o badaniach, sposobie stosowania leków, przebiegu ewentualnego leczenia. Analizy materiału badawczego dokonano przy użyciu programu IBM SPSS Statistics. Posłużono się testami chi $^{2}(p<0,01)$, U Manna-Whitneya oraz Kruskala-Wallisa $(p<0,05)$.

\section{Wyniki}

Przeprowadzona analiza wykazała brak istotnej statystycznie zależności między płcią (test chi $^{2}=1,256$, $p=0,986$ ), miejscem zamieszkania (test $\mathrm{chi}^{2}=5,161$, $\mathrm{p}=0,076$ ), wykształceniem (test $\mathrm{chi}^{2}=4,523, \mathrm{p}=0,340$ ) i wiekiem (test $\mathrm{chi}^{2}=2,793, p=0,593$ ) a chęcią otrzymania od lekarza POZ porad na temat działań, które w pozytywny sposób wpłynęłyby na stan zdrowia pacjenta. Niemalże wszystkie kobiety $(96,3 \%)$ i mężczyźni (93,3\%), mieszkańcy miast $(98 \%)$ i wsi $(91,8 \%)$, badani niezależnie do poziomu wykształcenia i przynależności do poszczególnych grup wiekowych wykazywali chęć uzyskania takich informacji od lekarza rodzinnego.

Nie wykazano istotnej statystycznie zależności między płcią (test chi ${ }^{2}=2,241, p=0,326$ ), miejscem zamieszkania (test $\mathrm{chi}^{2}=4,480, p=0,106$ ), wykształceniem (test chi $^{2}=2,999, p=0,558$ ) i wiekiem (test chi $^{2}=5,766$, $p=0,217)$ a chęcią posiadania wiedzy na temat prawdopodobnych przyszłych problemów zdrowotnych. Badani bez względu na poziom wykształcenia, miejsce zamieszkania czy płeć wykazywali średni stopień zaciekawienia prawdopodobnymi problemami zdrowotnymi, z jakimi, być może, będą się zmagać w przyszłości. Zaobserwowano, iż nieznacznie wraz z wiekiem badani rzadziej niż młodsi ankietowani woleli być świadomi przyszłych zaburzeń w stanie zdrowia.

Uzyskano istotną statystycznie zależność między płcią (test chi ${ }^{2}=7,608, p=0,022$ ), wiekiem (test $\mathrm{chi}^{2}=$ $10,496, p=0,033)$ a chęcią poznania przez pacjentów wyników swoich badań. Zdecydowanie więcej kobiet (73,6\%) niż mężczyzn $(48,9 \%)$ chciało zapoznać się z efektami badań (Tabela 1).

Tabela 1. Chęć poznania wyników przeprowadzonych badań w zależności od płci

Table 1. The desire to know the results of the research conducted on the basis of sex

\begin{tabular}{|c|c|c|c|}
\hline $\begin{array}{l}\text { Chce poznać wyniki prze- } \\
\text { prowadzonych badań/I want } \\
\text { to know the results of the } \\
\text { research }\end{array}$ & Tak/Yes & $\mathrm{Nie} / \mathrm{No}$ & $\begin{array}{l}\text { Odchylenie standardowe/ } \\
\text { Standard deviation }\end{array}$ \\
\hline Kobiety/Women & $73,6 \%$ & $24,5 \%$ & 0,27 \\
\hline Mężczyźni/Men & $48,9 \%$ & $40,0 \%$ & 0,16 \\
\hline
\end{tabular}

Źródło: opracowanie własne

Source: authors own analysis 
Wraz z wiekiem badanych rosła chęć zaznajomienia się z wynikami przeprowadzonych badań (Tabela 2).

Tabela 2. Wiek a chęć poznania wyników przeprowadzonych badań Table 2. Age and willingness to know the results of the research

\begin{tabular}{ccc}
\hline $\begin{array}{c}\text { Chce poznać wyniki przeprowadzonych badań// want to } \\
\text { know the results of the research }\end{array}$ & Tak/Yes & Nie/No \\
\hline $18-35$ lat/age & $57,1 \%$ & $42,9 \%$ \\
$36-45$ lat/age & $60,7 \%$ & $35,7 \%$ \\
$46-76$ lat/age & $68,6 \%$ & $17,1 \%$ \\
\hline
\end{tabular}

Źródło: opracowanie własne

Source: authors own analysis

Brak istotnej statystycznie zależności między miejscem zamieszkania (test $c h i^{2}=1,950, p=0,377$ ) i wykształceniem (test chi $^{2}=5,475, p=0,242$ ) a chęcią poznania rezultatów badań.

Wystąpiła istotna statystycznie zależność między miejscem zamieszkania (test chi $^{2}=14,131, p=0,001$ ) i wiekiem badanych (test chi ${ }^{2}=10,381, p=0,034$ ) a chęcią omówienia z lekarzem POZ wyników badań. Blisko połowa mieszkańców miast (49\%) i znaczna większość mieszkańców wsi (81,6\%) chciałaby, aby lekarz przedyskutował z nimi rezultaty badań (Tabela 3 ).

Tabela 3. Chęć omówienia z lekarzem wyników badań w zależności od miejsca zamieszkania

Table 3. Will want to discuss with the doctor the results of the study depending on the place of residence

\begin{tabular}{cccc}
\hline $\begin{array}{c}\text { Chcę, aby lekarz omówił wyniki moich } \\
\text { badań// want the doctor to discuss the } \\
\text { results of my research }\end{array}$ & Tak/Yes & $\begin{array}{c}\text { Nie/No } \\
\text { Odchylenie } \\
\text { standardowe/ } \\
\text { Standard } \\
\text { deviation }\end{array}$ \\
\hline Miasto/City & $49,0 \%$ & $43,1 \%$ & 0,18 \\
Wieś/Village & $81,6 \%$ & $10,2 \%$ & 0,34 \\
\hline
\end{tabular}

Źródło: opracowanie własne

Source: authors own analysis

Wraz z wiekiem badanych rósł odsetek osób, które chciały omówić z lekarzem wyniki badania (Tabela 4).

Tabela 4. Chęć omówienia z lekarzem wyników badań w zależności od wieku

Table 4. Desire to discuss with the doctor the results of the study, depending on age

\begin{tabular}{ccc}
\hline $\begin{array}{l}\text { Chcę, aby lekarz omówił wyniki moich badań/l want the } \\
\text { doctor to discuss the results of my research }\end{array}$ & Tak/Yes & Nie/No \\
\hline 18-35 lat/age & $50,0 \%$ & $44,4 \%$ \\
36-45 lat/age & $67,9 \%$ & $25,0 \%$ \\
46-76 lat/age & $77,8 \%$ & $11,1 \%$ \\
\hline
\end{tabular}

Źródło: opracowanie własne

Source: authors own analysis

Nie zaobserwowano, aby płeć ankietowanych (test chi $\left.^{2}=2,811, p=0,245\right)$ i poziom wykształcenia (test chi $\left.^{2}=5,629, p=0,229\right)$ wpływały na potrzebę omówienia przez lekarza wyników badań.

Nie wykazano istotnej statystycznie zależności między płcią (test chi ${ }^{2}=1,087, p=0,581$ ), miejscem zamieszkania (test chi ${ }^{2}=2,496, p=0,272$ ), wykształceniem (test chi $^{2}=2,038, p=0,729$ ) i wiekiem (test chi ${ }^{2}=2,807$, $p=0,591)$ a chęcią uzyskania od lekarza informacji o prawdopodobnym przebiegu choroby. Zarówno mężczyźni, jak i kobiety, badani bez względu na poziom wykształcenia, miejsce zamieszkania i reprezentowaną grupę wiekową w zdecydowanej większości chcieliby, aby lekarz POZ zapoznał ich z takimi informacjami.

Przeprowadzona analiza wykazała, że płeć (test chi $^{2}=1,791, p=0,408$ ) i poziom wykształcenia (test $\left.\mathrm{chi}^{2}=9,369, \mathrm{p}=0,053\right)$ nie wpływały na chęć uzyskania od lekarza POZ skierowania do lekarza specjalisty. $\mathrm{Na}$ możliwość skonsultowania stanu swojego zdrowia ze specjalistą rzutowały znacząco wiek (test chi ${ }^{2}=12,468$, $p=0,014$ ) i miejsce zamieszkania (test $\mathrm{chi}^{2}=17,967$, $p=0,000)$. Skierowanie do specjalisty najczęściej pragnęli uzyskać mieszkańcy wsi $(71,4 \%)$ (Tabela 5) oraz najstarsi badani (Tabela 6).

Tabela 5. Chęć uzyskania skierowania do specjalisty w zależności od miejsca zamieszkania

Table 5. Willingness to get referrals to a specialist depending on where you live

\begin{tabular}{cccc}
\hline $\begin{array}{c}\text { Chcę być kierowany do lekarza specjali-- } \\
\text { sty/l want to be referred to a specialist }\end{array}$ & Tak/Yes & Nie/No & $\begin{array}{c}\text { Odchylenie } \\
\text { standardowe/ } \\
\text { Standard } \\
\text { deviation }\end{array}$ \\
\hline Miasto/City & $29,4 \%$ & $54,9 \%$ & 0,16 \\
Wieś/Village & $71,4 \%$ & $24,5 \%$ & 0,28 \\
\hline
\end{tabular}

Źródło: opracowanie własne

Source: authors own analysis

Tabela 6. Chęć uzyskania skierowania do specjalisty w zależności od wieku

Table 6. Willingness to refer to a specialist according to age

\begin{tabular}{|c|c|}
\hline $\begin{array}{l}\text { Chcę być kierowany do lekarza specjalisty/l want to be } \\
\text { referred to a specialist }\end{array}$ & Tak/Yes Nie/No \\
\hline 18-35 lat/age & $27,8 \% \quad 61,1 \%$ \\
\hline $36-45$ lat/age & $57,1 \% \quad 32,1 \%$ \\
\hline 46-76 lat/age & $66,7 \% \quad 25,0 \%$ \\
\hline
\end{tabular}

Źródło: opracowanie własne

Source: authors own analysis

Wystąpiła istotna statystycznie zależność między wiekiem a chęcią otrzymania od lekarza POZ porad na temat przyjmowanych lekarstw (test chi $^{2}=14,653$, $p=0,005)$. Zaobserwowano, iż wraz z wiekiem rosła potrzeba uzyskania informacji o stosowaniu medykamentów (Tabela 7). 
Tabela 7. Chęć otrzymania porady na temat przyjmowanych lekarstw w zależności od wieku

Table 7. Willingness to receive advice on medications taken depending on age

\begin{tabular}{ccc}
\hline $\begin{array}{c}\text { Chcę porady na temat lekarstw, które przyjmuję// want } \\
\text { advice on the medications that it takes }\end{array}$ & Tak/Yes & Nie/No \\
\hline 18-35 lat/age & $38,9 \%$ & $44,4 \%$ \\
36-45 lat/age & $60,7 \%$ & $25,0 \%$ \\
46-76 lat/age & $80,6 \%$ & $8,3 \%$ \\
\hline
\end{tabular}

Źródło: opracowanie własne

Source: authors own analysis

Na potrzebę skonsultowania z lekarzem POZ kwestii zażywania leków nie wpływały poziom wykształcenia (test $c h i^{2}=5,227, p=0,265$ ), miejsce zamieszkania (test chi $^{2}=5,233, p=0,073$ ) i płeć (test chi $^{2}=0,872$, $p=0,647)$.

Nie wykazano istotnej statystycznie zależności między wiekiem (test chi ${ }^{2}=4,668, p=0,323$ ), wykształceniem (test chi $^{2}=0,482, p=0,975$ ), miejscem zamieszkania (test chi ${ }^{2}=5,304, p=0,071$ ), płcią (test chi ${ }^{2}=1,581$, $p=0,454)$ a chęcią otrzymania od lekarza informacji na temat objawów chorobowych. Badani bez względu na zmienne socjodemograficzne w znaczącej większości chcieli uzyskać od lekarza informacje na temat symptomów choroby. Zdecydowana większość badanych niezależnie od wieku (test $\mathrm{chi}^{2}=2,902, \mathrm{p}=0,574$ ), płci (test chi ${ }^{2}=0,923, p=0,630$ ), miejsca zamieszkania (test $\mathrm{chi}^{2}=1,670, \mathrm{p}=0,434$ ) i wykształcenia (test $\mathrm{chi}^{2}=1,355$, $p=0,852$ ) oczekiwała od lekarza wyjaśnień na temat stosowanego leczenia. Ponadto brak istotnej statystycznie zależności między wiekiem (test chi $^{2}=8,107$, $p=0,088$ ), wykształceniem (test $\operatorname{chi}^{2}=2,973, p=0,562$ ), miejscem zamieszkania (test $\mathrm{chi}^{2}=4,838, \mathrm{p}=0,089$ ) i płcią (test $\mathrm{chi}^{2}=0,022, p=0,989$ ) a chęcią posiadania wiedzy na temat możliwych skutków ubocznych swojej choroby. Zaobserwowano, iż chęć posiadania takiej wiedzy była odwrotnie proporcjonalna do wieku i wprost proporcjonalna do poziomu wykształcenia. Niezależnie od płci i miejsca zamieszkania zdecydowana większość badanych chciała być świadoma możliwych efektów ubocznych choroby.

Uzyskano istotną statystycznie zależność między płcią ( $p=0,001)$ i miejscem zamieszkania respondentów $(p=0,010)$ a poprawą samopoczucia w wyniku podzielenia się z kimś swoimi odczuciami. Taką potrzebę wskazały najczęściej kobiety $(61,1 \%)$ i mieszkańcy wsi (53,1\%). Brak istotnej statystycznie zależności między wiekiem (test chi ${ }^{2}=3,950, p=0,413$ ) i wykształceniem (test $\mathrm{chi}^{2}=6,766, \mathrm{p}=0,149$ ) a omawianą kwestią.

Wystąpiła istotna statystycznie zależność między płcią $(p=0,000)$, miejscem zamieszkania $(p=0,010)$, wykształceniem $(p=0,025)$, wiekiem (test chi ${ }^{2}=10,691$, $p=0,030)$ a chęcią otrzymania otuchy w trudnej chwi-

li. Zdecydowanie więcej kobiet (55,6\%) niż mężczyzn $(21,7 \%)$ oraz mieszkańców wsi $(55,1 \%)$ niż miast $(25,5 \%)$ wskazało na potrzebę pokrzepienia w ciężkiej sytuacji. Potrzeba uzyskania pocieszenia i pokrzepienia była wprost proporcjonalna do wieku (Tabela 8) i odwrotnie proporcjonalna do poziomu wykształcenia.

Tabela 8. Chęć otrzymania otuchy w trudnej chwili w zależności od wieku

Table 8. Wishing to receive reassurance at a difficult time depending on age

\begin{tabular}{ccc}
\hline $\begin{array}{c}\text { Chce, aby ktoś dodał mi otuchy w trudnej chwili/l want } \\
\text { somebody to cheer me up in a difficult moment }\end{array}$ & Tak/Yes & Nie/No \\
\hline 18-35 lat/age & $22,2 \%$ & $44,4 \%$ \\
36-45 lat/age & $50,0 \%$ & $39,3 \%$ \\
46-76 lat/age & $50,0 \%$ & $38,9 \%$ \\
\hline
\end{tabular}

Źródło: opracowanie własne

Source: authors own analysis

\section{Dyskusja}

Zagadnienie dotyczące oczekiwań pacjentów względem lekarzy ma bardzo złożoną naturę. Fakt podjęcia roli pacjenta zależy w dużej mierze od dobrych lub złych doświadczeń, powstałych podczas wcześniejszych kontaktów z przedstawicielami służby zdrowia. Doświadczenia te dotyczą nie tylko skuteczności przeprowadzanej terapii, ale i „(...) empatii, wsparcia, zrozumienia, zapewnienia poczucia bezpieczeństwa, właściwej komunikacji, a także rozległej wiedzy medycznej, rozsądku, taktu, kultury osobistej" pracowników medycznych [7]. Zdaniem Wrońskiego i wsp. to w gestii chorego leży decydowanie o własnym procesie terapeutycznym, a zadaniem świadczeniodawcy jest zapewnienie usługi odpowiadającej wymaganiom beneficjenta [8].

Jednym z głównych oczekiwań pacjentów jest uzyskanie wsparcia emocjonalnego podczas wizyty lekarskiej. Rotter i wsp. donoszą, iż istotnie wyższy poziom oczekiwań odnośnie wsparcia emocjonalnego otrzymywanego od lekarzy POZ wykazują pacjenci starsi, samotni, słabiej wykształceni, nieaktywni zawodowo. Badacze są zdania, że lekarze POZ powinni więcej uwagi poświęcić sytuacji życiowej swoich pacjentów. Wskazali także na istotną statystycznie zależność między płcią a chęcią otrzymania otuchy od lekarza POZ $(p=0,000)$, którą znacznie częściej pragnęły uzyskać kobiety [7]. Odmienne wyniki uzyskali Wołosewicz i wsp. Poszukiwanie wsparcia emocjonalnego u lekarza różnicują według badaczy zmienne, jak płeć, wiek, status społeczno-zawodowy, stan cywilny, wykształcenie, wskaźnik BMI. Zdaniem badaczy mężczyźni, osoby do 39. r.ż., 
pobierające rentę lub emeryturę, owdowiałe, z wyższym wykształceniem posiadają istotnie wyższy wskaźnik poszukiwania wsparcia emocjonalnego u lekarza [6]. Xhulia i wsp. zaobserwowali, iż na potrzebę wsparcia i otrzymanie wskazówek od personelu medycznego istotne wpływają wiek i miejsce zamieszkania pacjentów [9]. Z kolei Marcinowicz i wsp. donoszą, iż pacjenci oczekują od lekarza pierwszego kontaktu skuteczności ekspresywnej, na którą składają się wsparcie emocjonalne, uspokojenie i dodawanie otuchy świadczeniobiorcom [10]. Robaszkiewicz-Bouakaz i wsp. badali poziom oczekiwań wobec opieki medycznej wśród pozbawionych wolności mężczyzn. Ponad $80 \%$ badanych chciało uzyskać informacje o stosowanym leczeniu, posiadanych objawach i przyczynach ich stanu zdrowia. Niewiele ponad połowa respondentów (58\%) liczyła na wsparcie emocjonalne, przy czym byli to głównie starsi respondenci [11]. Badania własne wykazały, że ogólny poziom oczekiwań pacjentów dotyczący otrzymania otuchy jest dość wysoki. Wystąpiła istotna statystycznie zależność między wszystkimi analizowanymi zmiennymi socjodemograficznymi a chęcią otrzymania wsparcia w trudnej chwili. Potrzeba uzyskania pocieszenia była wprost proporcjonalna do wieku i odwrotnie proporcjonalna do poziomu wykształcenia. Wskazali na nią głównie kobiety i mieszkańcy wsi. Uzyskano także istotną statystycznie zależność między płcią i miejscem zamieszkania respondentów a poprawą samopoczucia w wyniku podzielenia się z kimś swoimi odczuciami, na co wskazali znacznie częściej kobiety oraz mieszkańcy wsi.

Strzelecka i wsp. analizowali opinie pacjentów powyżej 65. r.ż. na temat wymagań wobec lekarzy POZ z województwa świętokrzyskiego. Zespół dowiódł, iż wraz z wiekiem rosną oczekiwania pacjentów odnośnie uzyskiwanych informacji. Ponadto starsi świadczeniobiorcy wykazywali większą potrzebę wsparcia emocjonalnego niż młodsi ankietowani [12]. Odmienne wyniki uzyskały Andruszkiewicz i Basińska. Wskazują na istotne statystycznie różnice między wiekiem respondentów a ogólnym poziomem oczekiwań wobec lekarza oraz potrzebą wyjaśnienia charakteru choroby i uzyskania wsparcia. Im młodsi byli pacjenci, tym mieli większe oczekiwania względem lekarza, wymagali głębszego wytłumaczenia spektrum choroby i wsparcia emocjonalnego [13]. Wang i wsp. donoszą, że im młodsi pacjenci i gorszy jest stan ich zdrowia, tym oczekują od lekarza jakościowo lepszej komunikacji [14]. Podobnego zdania są Łukomska i wsp., którzy donoszą, że osoby starsze wykazują mniejsze oczekiwania wobec lekarzy oraz otrzymywanych usług medycznych [15]. Autorska analiza wykazała, że badani bez względu na grupę wiekową w średnim stopniu byli zaciekawieni prawdopodobnymi problema- mi zdrowotnymi, z jakimi, być może, będą się zmagać w przyszłości. Zaś wraz z wiekiem respondentów rosła chęć zapoznania się z wynikami przeprowadzonych badań i wzrastał odsetek osób, które chciałyby omówić je z lekarzem, a także rosła potrzeba uzyskania informacji o stosowaniu medykamentów.

Zadania lekarza w procesie komunikowania się z pacjentem to uzyskanie porozumienia i aktywizacja osoby objętej leczeniem. Niezbędne jest zatem nawiązanie odpowiedniej współpracy i kooperacji oraz udzielanie różnych form wsparcia beneficjentom świadczeń zdrowotnych. Vural i wsp. donoszą, iż umiejętności komunikacyjne pracowników służby zdrowia uznaje się za podstawowe czynniki skutecznie wpływające na stan zdrowia pacjenta i jego ogólne zadowolenie z podjętych metod leczenia [16]. Williams uważa, iż personel medyczny powinien realizować styl komunikowania się skoncentrowany na pacjencie. Ponadto sądzi, że empatia, współczucie płynące od lekarza podczas wizyty pozytywnie rzutują na poziom satysfakcji pacjentów [17]. Z kolei Ostrowska zwraca uwagę na obserwowane w relacjach pacjent - lekarz dysproporcje między społecznymi oczekiwaniami a praktyką społeczną [18].

W opinii Gill i wsp. pacjenci w głównej mierze oczekują od swojego lekarza odpowiednich kompetencji zawodowych i zrozumienia ich potrzeb zdrowotnych [19]. Podobne rezultaty uzyskano w badaniach własnych. Bez względu na zmienne socjodemograficzne badani chcieli uzyskać od lekarza POZ porady na temat działań, które w pozytywny sposób wpłynęłyby na stan ich zdrowia.

Wierzbińska-Karakuła i wsp. wykazali, iż większość pacjentów z terenu Polski południowo-wschodniej postrzega opiekę lekarza POZ jako zapewniającą godność i respektującą prawa pacjenta. Kobiety były bardziej zadowolone z informacji uzyskanych od lekarza niż mężczyźni [5]. Także w badaniach własnych to kobiety wykazywały wyższy niż panowie stopień zaciekawienia efektami badań i uzyskiwaniem pomocy i wsparcia od lekarza POZ.

W badaniach Marcinowicz i wsp. zdecydowana większość respondentów $(79,2 \%)$ wskazała na spełnienie ich oczekiwań podczas ostatniej wizyty lekarskiej. Ankietowani wśród głównych oczekiwań stawianych przed lekarzem rodzinnym wymieniali skuteczność instrumentalną (skuteczność leczenia, trafna diagnoza, poprawa stanu zdrowia, badanie fizykalne), informowanie pacjenta, relację pacjenta z lekarzem (słuchanie, zainteresowanie, zachowanie lekarza, poświęcony czas), kierowanie na badania diagnostyczne, wypisanie recepty, kierowanie do specjalisty, skuteczność ekspresywną (emocjonalne wsparcie), organizację wizyty i wypowiedzi ogólne [10]. Kolejne badania Marcinowicz i wsp. dotyczyły ustalenia przyczyn niezadowolenia pacjentów z opieki lekarza POZ. 
Badani wyróżnili trzy główne grupy przyczyn niezadowolenia ze świadczeń lekarza rodzinnego: niedociągnięcia w systemie POZ, w tym szczególnie trudności z uzyskaniem skierowania do specjalisty i na dodatkowe badania; w organizacji opieki i jakości świadczeń - niedostateczny wymiar czasu poświęcanego pacjentowi podczas wizyty lekarskiej, zbyt długie kolejki do lekarza; w postawach, umiejętnościach oraz pracy zwrócono uwage na brak zainteresowania pacjentem, ciepła, serdeczności, obojętność, rutynowe traktowanie i lekceważenie, opieszałość, lenistwo, przedmiotowe traktowanie. Ankietowani wskazali także na udzielanie niewystarczających informacji o stanie zdrowia, chorobie, jej skutkach, wynikach badań. Badacze na podstawie rezultatów z przeprowadzonej analizy wnioskowali, aby w procesie edukacji studentów medycyny zwracano większą uwagę na kształtowanie umiejętności interpersonalnych, indywidualnego traktowania pacjenta, właściwego przekazywania informacji, aktywnego słuchania i budowania zaufania [20].

„(...) pacjenci są coraz bardziej krytycznie nastawieni na proces leczenia i coraz częściej wymagają od profesjonalistów medycznych pełnego (i najlepiej, gdy zrozumiałego dla nich samych - pacjentów) zaangażowania ich wiedzy i dostępnych środków materialnych w proces leczenia (...)" [6]. Mykowska wśród głównych oczekiwań pacjentów wobec pracowników medycznych wymieniła potrzebę informacji, bezpieczeństwa, kontroli sytuacji, wsparcia społecznego, zainteresowania, szacunku, akceptacji, poufności, intymności i przyjaznej atmosfery [21]. W badaniach Moczydłowskiej i wsp. respondenci wśród najbardziej pożądanych cech charakteru u lekarzy wyróżnili zaufanie, bezinteresowność, odpowiedzialność, poszanowanie godności. Ponad połowa darzyła ich zaufaniem, stosowała się do ich rad, traktowała jako ekspertów, wierzyła w ich prawdomówność i umiejętność dotrzymania tajemnicy zawodowej [22].

\section{Wnioski}

Przeprowadzone badania pozwoliły na wysunięcie kilku znaczących wniosków:

1. Niemalże wszyscy badani wskazali na chęć uzyskania wsparcia od lekarza POZ w ciężkiej sytuacji.

2. W znaczącej większości respondenci domagali się od lekarza POZ omówienia wyników badań, uzyskania informacji o prawdopodobnym przebiegu choroby, jej objawach i skutkach ubocznych, przyjmowaniu lekarstw, podejmowanym leczeniu czy skierowania do lekarza specjalisty.

3. Niezależnie od zmiennych socjodemograficznych badani wykazywali znaczącą potrzebę otrzymania od lekarza POZ porad na temat działań, które w pozytywny sposób wpłynęłyby na stan ich zdrowia.

4. Badani bez względu na poziom wykształcenia, miejsce zamieszkania, płeć i wiek wykazywali średni stopień zaciekawienia prawdopodobnymi problemami zdrowotnymi, z jakimi, być może, będą się zmagać w przyszłości.

5. Na chęć poznania przez pacjentów wyników swoich badań istotny wpływ miały wiek i płeć badanych. Kobiety i najstarsi ankietowani wykazywali największą potrzebę zaznajomienia się z efektami badań.

\section{Piśmiennictwo}

1. van Marle HJ. The patient rules: the power of transference in the doctor-patient relationship. Nederlands Tijdschrift voor Geneeskunde. 2016; 160: D1219.

2. Małecka B, Marcinkowski JT. Satysfakcja pacjenta czynnikiem kształtującym współczesny rynek usług medycznych. Probl Hig Epidemiol. 2007; 88(1): 17-19.

3. Palczewska A. Jakość usług medycznych w opiece paliatywnej. Probl Piel. 2008; 16: 186-191.

4. Kurpas D, Wojtal M, Steciwko A, Drobnik J. Jakość usług medycznych świadczonych w opiece podstawowej w opinii pacjentów. Fam Med Prim Care Rev. 2008; 10(3): 483-485.

5. Wierzbińska-Karakuła S, Binkowska-Bury M, Burzyńska J, Januszewicz P. Respektowanie oczekiwań i praw pacjentów w podkarpackich jednostkach podstawowej opieki zdrowotnej jako element jakości usług zdrowotnych. Prz Med Uniw Rzesz. 2015; 1: 19-30.

6. Wołosewicz I, Kupcewicz E, Szypulska A, Fischer B. Oczekiwania pacjentów wobec lekarza i pielęgniarki w podstawowej opiece zdrowotnej. Przedsiębiorczość i Zarządzanie. 2013; XIV(10): 293-322.

7. Rotter I, Stańczak K, Laszczyńska M, Kemicer-Chmielewska E, Żułtak-Bączkowska K, Jasińska M et al. Oczekiwania wsparcia emocjonalnego pacjentów podstawowej opieki zdrowotnej w zależności od wybranych czynników demograficznych. Fam Med Prim Care Rev. 2013; 15(3): 381-383.

8. Wroński K, Bocian R. Dlaczego zakłady opieki zdrowotnej powinny badać satysfakcję pacjentów z oferowanych przez siebie usług medycznych? Piel Chir Angiol. 2009; 4: 127-130.

9. Xhulia D, Gerta J, Dajana Z, Koutelekos I, Vasilopoulou C, Skopelitou $\mathrm{M}$ et al. Needs of Hemodialysis Patients and Factors Affecting Them. Global J Health Sci. 2015; 8(6): 109-120.

10. Marcinowicz L, Grębowski R, Fiedorczuk I, Chlabicz S. Oczekiwania pacjentów związane z wizytą u lekarza rodzinnego: analiza treści i próba typologii. Fam Med Prim Care Rev. 2010; 12(1): 30-35.

11. Robaszkiewicz-Bouakaz R, Gawrońska K, Jurczak A, Wieder-Huszla S, Szkup M, Starczewska M et al. Oczekiwania wobec ambulatoryjnej opieki zdrowotnej wśród osób pozbawionych wolności. Med Health Sci Rev. 2015; 1(1): 27-33.

12. Strzelecka A, Nowak-Staż G, Karakiewicz B. Expectations of patients towards a primary care physician, related to the reason for the current visit, with particular emphasis on patients aged 65+. Fam Med Prim Care Rev. 2015; 3: 215-218. 
13. Andruszkiewicz A, Basińska A. Stan psychiczny pacjentów na etapie wczesnej i późnej starości a ich oczekiwania wobec lekarza. Psychiatria Pol. 2016; 50(5): 1001-1014.

14. Wang G, Xie J, Hu Y. Doctor-outpatient communications in Chinese public hospitals: a cross-sectional survey. Lancet. 2016; DOI: 10.1016/S0140-6736(16)31965-1.

15. Łukomska A, Szrajda J, Nowakowska I. Satysfakcja osób starszych z usług świadczonych przez lekarza rodzinnego. Gerontol Pol. 2012; 20(2): 68-72.

16. Vural F, Ciftci S, Cakiroglu Y, Vural B. Patient satisfaction with outpatient health care services: evaluation of the components of this service using regression analysis. North Clin Istanbul. 2014; 1(2): 71-77.

17. Williams S, Weinman J, Dale J. Doctor-patient communication and patient satisfaction: a review. Fam Pract. 1998; 15: 480 .

18. Ostrowska A. Relacja pacjent-lekarz: nowa jakość? Prom Zdr. 2001; (21): 109-121.

19. Gill V, Bridges S, McNaughton Nicholls C. The standards expected of doctors. Patient \& public attitudes. Final report. National Centre for Social Research; 2012.

20. Marcinowicz L, Górska A, Chlabicz S. Przyczyny niezadowolenia pacjentów z opieki lekarza rodzinnego w świetle badań ankietowych - analiza odpowiedzi na pytania otwarte. Prz Lek. 2007; 64(9): 559-562.
21. Mykowska A. Satysfakcja pacjenta a jakość obsługi medycznej. Zdr Publ Zarządz. 2002; 4: 69-73.

22. Moczydłowska A, Krajewska-Kułak E, Kózka M, Bielski K. Oczekiwania chorych wobec personelu lekarskiego. Hygeia Public Health. 2014; 49(1): 142-151.

Artykuł przyjęty do redakcji: 05.06.2017

Artykuł przyjęty do publikacji: 23.01.2018

Źródło finansowania: Praca nie jest finansowana z żadnego źródła. Konflikt interesów: Autorzy deklarują brak konfliktu interesów.

\author{
Adres do korespondencji: \\ Katarzyna Pawlikowska-Łagód \\ ul. Stanisława Staszica 4-6 \\ 20-081 Lublin \\ tel.: 814486850 \\ e-mail: katarzyna.pawlikowska21@gmail.com \\ Zakład Etyki i Filozofii Człowieka \\ Uniwersytet Medyczny w Lublinie
}

